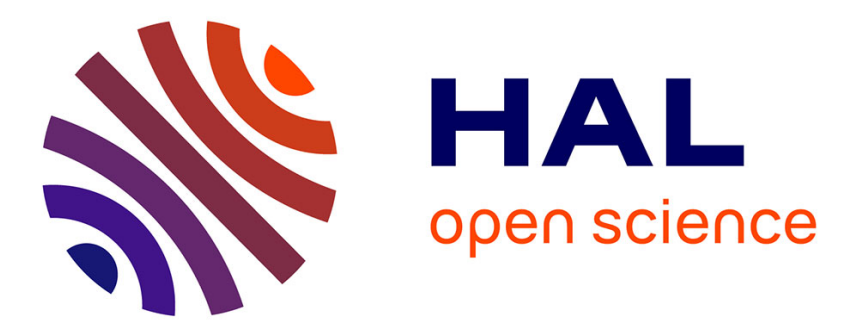

\title{
Unexplained infertility: live-birth's prognostic factors to determine the ART management
}

\author{
Alexandra Ohannessian, Anderson Loundou, Audrey Gnisci, Odile \\ Paulmyer-Lacroix, Jeanne Perrin, Blandine Courbiere
}

\section{- To cite this version:}

Alexandra Ohannessian, Anderson Loundou, Audrey Gnisci, Odile Paulmyer-Lacroix, Jeanne Perrin, et al.. Unexplained infertility: live-birth's prognostic factors to determine the ART management. Minerva Ginecologica, 2017. hal-01794748

\section{HAL Id: hal-01794748 \\ https://hal-amu.archives-ouvertes.fr/hal-01794748}

Submitted on 17 May 2018

HAL is a multi-disciplinary open access archive for the deposit and dissemination of scientific research documents, whether they are published or not. The documents may come from teaching and research institutions in France or abroad, or from public or private research centers.
L'archive ouverte pluridisciplinaire $\mathbf{H A L}$, est destinée au dépôt et à la diffusion de documents scientifiques de niveau recherche, publiés ou non, émanant des établissements d'enseignement et de recherche français ou étrangers, des laboratoires publics ou privés. 


\title{
Unexplained infertility: live-birth's prognostic factors to determine the ART management
}

\author{
Alexandra OHANNESSIAN ${ }^{1}$, Anderson LOUNDOU ${ }^{2}$, Audrey GNISCI ${ }^{1}$, \\ Odile PAULMYER-LACROIX 1,3, Jeanne PERRIN 1,4, Blandine COURBIERE 1, 4 *
}

1Pôle Femmes-Parents-Enfants, Centre Clinico-Biologique d'AMP-CECOS, AP-HM La Conception, Marseille, France; ${ }^{2} \mathrm{EA} 3279$, Self-Perceived Health Assessment Research Unit, Aix-Marseille University, Marseille, France; ${ }^{3}$ Department of Histology-Embryology, Faculty of Medicine, Aix-Marseille University, Marseille, France; ${ }^{4}$ Aix Marseille Université, CNRS, IRD, Avignon University, IMBE UMR 7263, Marseille, France

*Corresponding author: Blandine Courbiere, Pôle Femmes-Parents-Enfants - Centre Clinico-Biologique d'AMP, AP-HM La Conception, 147 bd Baille, 13005 Marseille, France. E-mail: blandine.courbiere@univ-amu.fr

\section{A B S T R A C T}

BACKGROUND: The purpose of this retrospective observational study was to identify prognostic factors that lead to a live birth (LB) in couples with unexplained infertility in order to define the best assisted-reproductive technique (ART) strategy.

METHODS: Prognostic factors of couples with unexplained infertility managed initially with gonadotropin intrauterine inseminations (IUI) at a single university fertility center were analyzed. Infertility was not considered "unexplained" in case of mild male infertility and suspicion of diminished ovarian reserve (FSH>10 IU/L). ART management consisted to start with IUI cycles and then, if failure, to propose in vitro fertilization (IVF). Couples were compared according to the results of IUI cycles in terms of LB.

RESULTS: Between January 2011 and July 2015, 133 couples with unexplained infertility were included (320 IUI cycles). The average age of women was $31.6 \pm 4.6$ years and the average number of IUI per couple was $2.4 \pm 1.2$. The IUI live birth rate (LBR) was $37.6 \%$, with an average of 2 cycles to obtain a pregnancy. For 63 couples, no pregnancy occurred after IUI cycles. The prognostic factors of the two groups "LB after IUI" vs. "no LB after IUI" were not statistically different. The remaining 20 couples had a spontaneous pregnancy with a LB. Cumulative LBR, including spontaneous and ART pregnancies, was $65.7 \%$. Of the 63 couples with no LB after IUI, 33.3\% dropped-out from infertility treatments before starting IVF.

CONCLUSIONS: To avoid couple's drop-out, we advise to start infertility treatment for unexplained infertility with two IUI before undergoing IVF if IUI failure.

Key words: Infertility - Fertilization in vitro - Reproductive techniques, assisted - Pregnancy.

\begin{abstract}
$\mathrm{A}$ bout 48.5 million couples worldwide would be infertile in the word. ${ }^{1}$ In France, 1 in 5 couple consults for infertility. ${ }^{2}$ In $10 \%$ to $30 \%$ of couples with infertility, no etiology is identifiable, that is usually called unexplained infertility. ${ }^{3-7}$ However, the diagnosis of unexplained infertility requires all the necessary diagnostic tests to exclude an etiology, after
\end{abstract}

ensuring the existence and regularity of unprotected sexual intercourse. Depending on the country, recommended tests may be different. Nevertheless, all the societies of reproductive medicine agree with semen analysis, assessment of the integrity of the female genital tract and the absence of ovulation disorder. The assessment of ovarian reserve by day 3 serum 
follicle-stimulating hormone (FSH) level, serum anti-Müllerian hormone (AMH) level and antral follicular count (AFC) remains controversial.7-10 Laparoscopy should be performed in case of suspicion of tubal or pelvic pathology. ${ }^{7-9}$ Chlamydiae trachomatis serology is not systematically recommended; in case of seropositivity, tubal abnormalities are suspected and a laparoscopy should be performed. ${ }^{9}$

Several management of unexplained infertility are proposed: expectant management, intrauterine insemination (IUI) with ovarian stimulation and then, if unsuccessful, in vitro fertilization (IVF), or starting the treatment with IVF.4, 6, 11-27 There is no international consensus on the best strategy for the management of unexplained infertility. For example, the Guidelines of the National Institute for Health and Care Excellence on infertility advise couples to try to conceive for a total of 2 years, including up to one year before their infertility investigations, before considering IVF. ${ }^{7}$ In France, the choice between IUI or IVF remains to the physician, depending on prognostic factors such as age and infertility duration, without clear cutoffs. ${ }^{9}$ However, these ART options are greatly different in terms of cost, hardship and risk for the woman. Thus, the aim of our study was to identify live birth's (LB) prognostic factors of couples with unexplained infertility in order to define the best infertility treatment.

\section{Materials and methods}

The study protocol was approved by the French Committee of Ethics for Research in Obstetrics and Gynecology in January 2016 (CEROG 2015-GYN-1204). Informed consent was obtained from all participants.

\section{Patients}

We conducted a retrospective observational study in a single university fertility center in France. The data were collected from the medical records of couples. We included all the couples managed for unexplained infertility and who underwent their first IUI between January 2011 and June 2015.
Infertility was defined by the lack of pregnancy after one year of regular unprotected intercourse. To define the unexplained infertility, no etiology must be found after infertility investigations: for the man, at least two normal semen analyses, according to World Health Organization criteria. ${ }^{28}$ If one semen parameter (sperm concentration, motility, morphology) was out of the reference range, the couple was not included in the study. For the woman, the assessment of the tubal patency and uterine cavity was made by hysterosalpingogram (HSG) and pelvic ultrasound. The ovarian reserve was assessed by antral follicle count (AFC), serum AMH level (ng/mL, Kit Beckman-Coulter, Immunotech) and day 3 serum FSH level (IU/L). In case of suspected diminished ovarian reserve (DOR, FSH $>10$ IU/L), the couple was not included. In case of suspected tubal pathology, a laparoscopy was proposed to women.

The management of unexplained infertility consisted to start with gonadotropin IUI and then, if unsuccessful, to propose IVF. The maximum number of IUI before undergoing IVF was determined in the center depending on the woman age: up to 4 IUI up to 38 -yearsold, up to 2 after 38 -years-old.

\section{Prognostic factors}

The prognostic factors that we aimed to study were: age, Body Mass Index (BMI) and smoking status for both man and woman, infertility duration, type of infertility (primary or secondary), AFC, day 3 serum FSH level (UI/L), serum AMH level (Beckman-Coulter kit, ng/mL), woman Chlamydiae trachomatis serology, a diagnostic laparoscopy in the initial workup for infertility. We also assessed the number of IUI cycles, pregnancy outcomes (with IUI or IVF), and spontaneous pregnancies with the time to conceive.

\section{Statistical analysis}

The main analysis compared prognostic factors between two groups of couples: the couples with a LB after IUI, and the couples 
who should undergo IVF after IUI failure. A secondary analysis compared two groups of couples: couples with a spontaneous pregnancy and LB, and the childless couples despite time trying to conceive spontaneously associated to ART management (IUI \pm IVF).

IBM SPSS Statistics version 20.0 (Inc., IL., USA) software was used for data analysis. Statistical significance was defined as $\mathrm{P}<0.05$. Quantitative data were expressed as mean \pm standard deviation (SD) or as medians with range (minimum, maximum), qualitative data were expressed as numbers and percentages. Qualitative data were compared using the Pearson's $\chi^{2}$ Test or Fisher's Exact Test when available. The relationship between a dichotomous variable and a quantitative variable was assessed using the Student $t$ test or the nonparametric Mann-Whitney Test. If the qualitative variable had more than two categories, the F Test ANOVA was used.

\section{Results}

Between January 2011 and July 2015, 133 couples with unexplained infertility were included, corresponding to 320 gonadotropin IUI cycles. The average number of IUI by couple was $2.4 \pm 1.2$. At the first cycle, the mean age was $31.6 \pm 4.6$ years for women, $34.9 \pm 6.2$ years for men. Primary infertility was observed on $67 \%$ of couples. The mean infertility duration at first cycle was $3.1 \pm 1.6$ years. Current smoking was observed on $32 \%$ of women and $40 \%$ of men. Mean BMI was $24.7 \pm 5.6 \mathrm{~kg} / \mathrm{m}^{2}$ for women, $24.4 \pm 3.4 \mathrm{~kg} / \mathrm{m}^{2}$ for men. Mean AFC was $17.6 \pm 8.5$. Mean value of women's basal FSH level was $6.5 \pm 1.7 \mathrm{IU} / \mathrm{L}$, mean serum level of AMH was $4.0 \pm 2.7 \mathrm{ng} / \mathrm{mL}$. Chlamydiae trachomatis antibody was tested in 52 women $(39 \%)$, and 6 women were seropositive. Ten women $(7.5 \%)$ had a diagnostic laparoscopy, and no pelvic pathology was found.

Among the 133 couples included, 50 couples had a LB after IUI, most of the time after the second IUI cycle. Twenty couples had a spontaneous pregnancy leading to a LB. Mean time to spontaneous pregnancy was $3.7 \pm 1.6$ years. For the remaining 63 couples, IVF was decided after several failed IUI. Of these 63 couples, 21 dropped-out from infertility treatments, before starting IVF. Seventeen couples had a pregnancy after IVF (fresh and frozenthawed embryo transfer) with LB. It was the first IVF attempt for two thirds of couples. Prognostic factors of the 50 couples with a pregnancy after IUI were compared with those of the 63 couples who should have started IVF, without any difference (Table I).

Moreover, the 20 couples who finally had a spontaneous pregnancy were compared with the childless couples despite IUI and IVF, without any prognostic factor being highlighted (Table II). Finally, cumulative LB rate (LBR), including spontaneous and ART pregnancies, for couples who were managed for unexplained infertility was $65.7 \%(\mathrm{~N} .=87)$.

\section{Discussion}

In the management of unexplained infertility, the choice between IUI and IVF is still

TABLE I.-Prognostic factors of live birth after IUI.

\begin{tabular}{lccc}
\hline & Live birth after IUI, N. $=50$ & IUI failure, $\mathrm{N} .=63$ & P value \\
\hline Women's age (y), mean (SD) & $30.8 \pm 4.4$ & $32.1 \pm 4.7$ & 0.1 \\
Men's age (y), mean (SD) & $34.6 \pm 6.1$ & $34.5 \pm 5.9$ & 0.9 \\
Women's BMI (kg/m²), mean (SD) & $25.7 \pm 5.9$ & $24.3 \pm 5.8$ & 0.2 \\
Men's BMI (kg/m²), mean (SD) & $24.3 \pm 3.6$ & $24.5 \pm 3.7$ & 0.8 \\
Female smokers, (N.)\% & $18(36)$ & $20(31.7)$ & 0.7 \\
Male smokers, (N.)\% & $18(36)$ & $28(44.4)$ & 0.4 \\
Primary infertility, (N.)\% & $31(62)$ & $45(71.4)$ & 0.3 \\
Infertility duration (y), mean (SD) & $3.2 \pm 1.7$ & $3.1 \pm 1.5$ & 0.9 \\
FSH (UI/L), mean (SD) & $6.2 \pm 1.9$ & $6.8 \pm 1.6$ & 0.05 \\
AMH (ng/mL), mean (SD) & $4.2 \pm 3.0$ & $4.1 \pm 2.5$ & 0.9 \\
AFC, mean (SD) & $18.2 \pm 9.5$ & $17.1 \pm 7.8$ & 0.6 \\
\hline
\end{tabular}


TABLE II.-Prognostic factors of LBR after spontaneous pregnancy.

\begin{tabular}{lccc}
\hline & $\begin{array}{c}\text { Spontaneous pregnancy } \\
\text { and live birth, N.=20 }\end{array}$ & $\begin{array}{c}\text { Childless after } \\
\text { IUI } \pm \text { IVF, N.=46 }\end{array}$ & P value \\
\hline Women's age (y), mean (SD) & $32.1 \pm 4.5$ & $32.1 \pm 5.1$ & 1 \\
Men's age (y), mean (SD) & $36.8 \pm 7.3$ & $35.1 \pm 6.2$ & 0.3 \\
Women's BMI (kg/m²), mean (SD) & $23.3 \pm 3.7$ & $24.2 \pm 5.8$ & 0.5 \\
Men's BMI (kg/m²), mean (SD) & $24.5 \pm 2.0$ & $24.5 \pm 4.0$ & 1 \\
Female smokers, (N.) \% & $4(20)$ & $16(34.8)$ & 0.2 \\
Male smokers, (N.) \% & $6(30)$ & $22(47.8)$ & 0.2 \\
Primary infertility, (N.) \% & $13(65)$ & $35(76.1)$ & 0.4 \\
Infertility duration (y), mean (SD) & $2.6 \pm 1.2$ & $3.1 \pm 1.5$ & 0.3 \\
FSH (UI/L), mean (SD) & $6.4 \pm 1.4$ & $6.8 \pm 1.7$ & 0.4 \\
CFA, mean (SD) & $18.2 \pm 9.6$ & $17.0 \pm 8.6$ & 0.7 \\
AMH (ng/mL), mean (SD) & $3.4 \pm 2.2$ & $3.8 \pm 2.0$ & 0.6 \\
\hline
\end{tabular}

debated. Our study wanted to assay LB's prognostic factors in these infertile couples in order to counsel them the best as possible: IUI prior IVF or starting immediately with IVF? Our study did not show any predictive factor of LB after IUI in these couples. LBR after IUI was $38 \%$. Most of the time, 2 IUI cycles were required to be pregnant.

In 2014, Kaser et al. published a secondary analysis of 2 trials, FASTT and FORT-T, including 603 infertile women aged 21 to 42 years, randomized to conventional or accelerated treatment with IUI and/or IVF (2717 total cycles). Women were stratified in 4 groups according to basal FSH and estradiol. Women with FSH of $10-15 \mathrm{IU} / \mathrm{L}$ and estradiol $\geq 40 \mathrm{pg} /$ $\mathrm{mL}$ on day 3 testing were unlikely to achieve LB after IUI. ${ }^{29}$ However, FSH of $10 \mathrm{IU} / \mathrm{L}$ is highly suggestive of DOR, and could explain the "unexplained" infertility. In our study, we excluded women with hormone profile suggesting a DOR. The difficulty of analyzing the literature is due to differences in the definition of "unexplained" infertility and the paraclinic exams that have led to this diagnosis. Ideally, we should use "unexplained infertility" only with a normal complete workup including pelvic ultrasound, HSG, hormone profile, assessment of ovarian reserve, a Chlamydia trachomatis serology and for male a normal semen analysis. ${ }^{30}$ In addition, diagnostic laparoscopy is not routinely performed for these women. Devranoglu et al. published a cross-sectional study including couples with unexplained infertility, with women at the age $\leq 36$ years with at least unilateral tubal patency at HSG: 105 women with a day $3 \mathrm{FSH} \geq 10 \mathrm{IU} / \mathrm{L}$ (170 IUI cycles) were compared to 95 women with a normal FSH (170 IUI cycles too). hCG positivity, clinical and ongoing pregnancy rates did not differ between women with normal and elevated FSH levels $(\mathrm{P}=0.2,0.3$ and 0.4 , respectively). Thus, according to this study, in women under 36 years, basal serum FSH was not a prognostic factor for pregnancy after IUI. ${ }^{31}$ Hansen et al. published a secondary analysis of a prospective, randomized, multicenter clinical trial including 900 couples with unexplained infertility who underwent IUI treatment, up to 4 cycles. Ovarian stimulation was performed with clomiphene citrate, letrozole, or gonadotropins. Woman's age, infertility duration, level of income and prior pregnancy loss were significant predictors of LB. In this study, the FSH level was not studied in contrast to AMH that was not correlated with the LBR, confirming the data from our study. ${ }^{32}$ Tjon-Kon-Fat et al. published a secondary analysis of a randomized controlled trial including 116 couples with unexplained or mild male subfertility. The couples were randomized to one cycle of IVF with elective single embryo transfer with subsequent frozen-thawed embryo transfers or 3 cycles of IUI. Female age and infertility duration were not associated with better ongoing pregnancy chances after IVF compared to IUI. Only when prewash total motile count was lower than 110 $\left(x 10^{6}\right.$ spermatozoa $\left./ \mathrm{mL}\right)$, the probability of ongoing pregnancy was higher in women al- 
located to IVF. This study included a heterogeneous population, with men with abnormal semen analysis. ${ }^{33}$

A recent retrospective cohort study by Geisler et al. included 851 couples with unexplained infertility, mild endometriosis, one patent Fallopian tube, mild male infertility or ovulatory dysfunction, up to 3 cycles IUI. At each attempt, more than $70 \%$ couples were couples with unexplained infertility. Independent associates of successful outcome factors were lower age and multiparity, for all the couples and the subgroup of unexplained infertility. The unadjusted cumulative pregnancy rate for LB per cycle started, over three cycles, was $34.9 \%$, which is near from our LBR of $37.6 \%$. In this study, more than $90 \%$ of total LBs with IUI is achieved during the first 2 cycles, corroborating our conclusion. ${ }^{34}$

\section{Limitations of the study}

The strength of our study was to be very restrictive on the couples' inclusion criteria. We did not include couples with mild male infertility, even with relatively mild sperm abnormalities, neither women with a suspicion of DOR $(\mathrm{FSH}>10 \mathrm{IU} / \mathrm{L}) .{ }^{8}$ So, we have included a very homogeneous population of couples whose infertility seemed truly unexplained. The very restrictive inclusion criteria, however, lead to include only a small population, even if the data have been studied over many years. The lack of significant results could be correlated with a lack of study power. One can also criticize the retrospective design of the study, the lack of randomization, and the long study period during which management changes could have taken place. Chlamydiae trachomatis seropositivity is associated with a lower natural conception rate and a lower likelihood of pregnancy after IUI, even with patent fallopian tubes. ${ }^{30,} 35$ In our study, less than half of women (39\%) were tested for Chlamydiae trachomatis, and we are not able not analyze this factor's reliably. The systematic prescription of the Chlamydiae trachomatis serology before IIU in our ART center is the result of recent management changes. Moreover, in our study, only 10 women $(7.5 \%)$ had a diagnostic laparoscopy, while it may be discussed of the infertility work-up despite normal HSG. Indeed, in unexplained infertility, endometriosis stage 1 or 2 , pelvic adhesions or tubal disease are found in $49 \%$ to $90.5 \%$ of women. ${ }^{36}$

Among the 133 couples included, IUI management failed for 63 couples. A third of these couples stopped infertility treatment after these failures, while an IVF treatment should have been recommended to them. This highlights the high rate of drop-out in infertility treatments, corroborating data from other studies on the subject. $37-40$ In our study, the mean infertility duration was $3.1 \pm 1.6$ years, with a minimum and a maximum of 1 and 8 years respectively, which is relatively long. Added to the time required to perform several IUI and the burnout due to repeated failures, this could contribute to discouraging some couples. So do not let the couples waste their time and let them start directly infertility management by IVF or right after two or three failed IUI cycles.

\section{Conclusions}

Prognostic factors for pregnancy in the context of unexplained infertility do not seem to exist. ${ }^{41}$ This study suggests the interest to start the treatment with up to 2 gonadotropin IUI attempts for any couple whose infertility is considered unexplained because IUI is less invasive and less expensive than IVF.

Moreover, chance of spontaneous pregnancy in these couples should be considered. Indeed, it has been shown that the diagnosis of infertility and its treatment could lead to sexual dysfunction and less frequent sexual intercourse. ${ }^{42-48}$ It is important to track sexual dysfunction and reassure the couple on natural conception.

\section{References}

1. Mascarenhas MN, Flaxman SR, Boerma T, Vanderpoel $\mathrm{S}$, Stevens GA. National, regional, and global trends in infertility prevalence since 1990: a systematic analysis of 277 health surveys. PLoS Med 2012;9:e1001356. 
2. Ohannessian M, Gamerre A. Épidémiologie de la fertilité. EMC - Gynécologie 2014;9:1-7.

3. Hull MG, Glazener CM, Kelly NJ, Conway DI, Foster PA, Hinton RA, et al. Population study of causes, treatment, and outcome of infertility. Br Med J (Clin Res Ed) 1985;291:1693-7.

4. Kamath MS, Bhattacharya S. Demographics of infertility and management of unexplained infertility. Best Pract Res Clin Obstet Gynaecol 2012;26:729-38.

5. Sadeghi MR. Unexplained infertility, the controversial matter in management of infertile couples. J Reprod Infertil $2015 ; 16: 1-2$

6. Ray A, Shah A, Gudi A, Homburg R. Unexplained infertility: an update and review of practice. Reprod Biomed Online 2012;24:591-602.

7. Royal College of Obstetricians and Gynaecologists. Fertility: assessment and treatment for people with fertility problems. NICE Clinical Guideline. February 2013.

8. Practice Committee of the American Society for Reproductive Medicine. Diagnostic evaluation of the infertile female: a committee opinion. Fertil Steril 2015;103:e4450 .

9. Collège National des Gynécologues et Obstétriciens Français. Recommandations pour la Pratique Clinique. La prise en charge du couple infertile; 2010 [Internet]. Available from http://www.cngof.asso.fr/D PAGES/ PURPC 00.HTM [cited 2017, May 31].

10. Arrêté $\overline{\text { du }} 22$ juin 2015 définissant les règles de bonnes pratiques applicables à la stimulation ovarienne y compris lorsqu'elle est mise en œuvre indépendamment d'une technique d'assistance médicale à la procréation [Internet]. Available from https://www.legifrance.gouv. fr/affichTexte.do?cidTexte=JORFTEXT000030830477 \&dateTexte $=20150703$ [cited 2017, May 31]

11. Steures P, van der Steeg JW, Hompes PG, Habbema JD, Eijkemans MJ, Broekmans FJ, et al. Collaborative Effort on the Clinical Evaluation in Reproductive Medicine. Intrauterine insemination with controlled ovarian hyperstimulation versus expectant management for couples with unexplained subfertility and an intermediate prognosis: a randomised clinical trial. Lancet 2006;368:216-21.

12. Custers IM, van Rumste MM, van der Steeg JW, van Wely M, Hompes PG, Bossuyt P, et al.; CECERM. Longterm outcome in couples with unexplained subfertility and an intermediate prognosis initially randomized between expectant management and immediate treatment. Hum Reprod 2012;27:444-50.

13. Gianaroli L, Racowsky C, Geraedts J, Cedars M, Makrigiannakis A, Lobo R. Best practices of ASRM and ESHRE:a journey through reproductive medicine. Hum Reprod 2012;27:3365-79.

14. Bensdorp AJ, Tjon-Kon-Fat RI, Bossuyt PM, Koks CA, Oosterhuis GJ, Hoek A, et al. Prevention of multiple pregnancies in couples with unexplained or mild male subfertility: randomised controlled trial of in vitro fertilisation with single embryo transfer or in vitro fertilisation in modified natural cycle compared with intrauterine insemination with controlled ovarian hyperstimulation. BMJ 2015;350:g7771

15. Tjon-Kon-Fat RI, Bensdorp AJ, Bossuyt PM, Koks C, Oosterhuis GJ, Hoek A, et al. Is IVF-served two different ways-more cost-effective than IUI with controlled ovarian hyperstimulation? Hum Reprod 2015;30:2331-9.

16. Veltman-Verhulst SM, Hughes E, Ayeleke RO, Cohlen BJ. Intra-uterine insemination for unexplained subfertility. Cochrane Database Syst Rev 2016;2:CD001838.

17. ESHRE Capri Workshop Group. Intrauterine insemination. Hum Reprod Update 2009;15:265-77.

18. van Rumste MM, Custers IM, van Wely M, Koks CA, van Weering HG, Beckers NG, et al. IVF with planned single-embryo transfer versus IUI with ovarian stimu- lation in couples with unexplained subfertility: an economic analysis. Reprod Biomed Online 2014;28:33642

19. Aboulghar M, Mansour R, Serour G, Abdrazek A, Amin Y, Rhodes C. Controlled ovarian hyperstimulation and intrauterine insemination for treatment of unexplained infertility should be limited to a maximum of three trials. Fertil Steril 2001;75:88-91.

20. Goverde AJ, McDonnell J, Vermeiden JP, Schats R, Rutten FF, Schoemaker J. Intrauterine insemination or in-vitro fertilisation in idiopathic subfertility and male subfertility: a randomised trial and cost-effectiveness analysis. Lancet 2000;355:13-8.

21. Reindollar RH, Regan MM, Neumann PJ, Levine BS, Thornton KL, Alper MM, et al. A randomized clinical trial to evaluate optimal treatment for unexplained infertility: the fast track and standard treatment (FASTT) trial. Fertil Steril 2010;94:888-99.

22. Pandian Z, Gibreel A, Bhattacharya S. In vitro fertilisation for unexplained subfertility. Cochrane Database Syst Rev 2015;CD003357.

23. Goldman MB, Thornton KL, Ryley D, Alper MM, Fung $\mathrm{JL}$, Hornstein MD, et al. A randomized clinical trial to determine optimal infertility treatment in older couples: the Forty and Over Treatment Trial (FORT-T). Fertil Steril 2014;101:1574-81.e1-2.

24. Pashayan N, Lyratzopoulos G, Mathur R. Cost-effectiveness of primary offer of IVF vs. primary offer of IUI followed by IVF (for IUI failures) in couples with unexplained or mild male factor subfertility. BMC Health Serv Res 2006;6:80.

25. Custers IM, König TE, Broekmans FJ, Hompes PG, Kaaijk E, Oosterhuis J, et al. Couples with unexplained subfertility and unfavorable prognosis:a randomized pilot trial comparing the effectiveness of in vitro fertilization with elective single embryo transfer versus intrauterine insemination with controlled ovarian stimulation. Fertil Steril 2011;96:1107-11.e1.

26. Quaas A, Dokras A. Diagnosis and treatment of unexplained infertility. Rev Obstet Gynecol 2008;1:69-76.

27. Brandes M, Hamilton CJ, van der Steen JO, de Bruin JP, Bots RS, Nelen WL, et al. Unexplained infertility: overall ongoing pregnancy rate and mode of conception. Hum Reprod 2011;26:360-8.

28. Cooper TG, Noonan E, von Eckardstein S, Auger J, Baker HW, Behre HM, et al. World Health Organization reference values for human semen characteristics. Hum Reprod Update 2010;16:231-45.

29. Kaser DJ, Goldman MB, Fung JL, Alper MM, Reindollar $\mathrm{RH}$. When is clomiphene or gonadotropin intrauterine insemination futile? Results of the Fast Track and Standard Treatment Trial and the Forty and Over Treatment Trial, two prospective randomized controlled trials. Fertil Steril 2014;102:1331-7.

30. Steiner AZ, Diamond MP, Legro RS, Schlaff WD, Barnhart KT, Casson PR, et al. Reproductive Medicine Network. Chlamydia trachomatis immunoglobulin G3 seropositivity is a predictor of reproductive outcomes in infertile women with patent fallopian tubes. Fertil Steril 2015:104:1522-6.

31. Devranoğlu B, Özdamar Ö, Köle E, Eken MK, Bozdağ H, Doğer E. Do younger women with elevated basal follicular stimulating hormone levels undergoing gonadotropin-stimulated intrauterine insemination cycles represent compromised reproductive outcomes? Eur J Obstet Gynecol Reprod Biol 2016;199:141-5.

32. Hansen KR, He AL, Styer AK, Wild RA, Butts S, Engmann L, et al.; Eunice Kennedy Shriver National Institute of Child Health and Human Development Reproductive Medicine Network. Predictors of pregnancy and livebirth in couples with unexplained infertility after ovar- 
ian stimulation-intrauterine insemination. Fertil Steril 2016;105:1575-83.

33. Tjon-Kon-Fat RI, Tajik P, Custers IM, Bossuyt PM, van der Veen F, van Wely M, et al. Can we identify subfertile couples that benefit from immediate in vitro fertilisation over intrauterine insemination? Eur J Obstet Gynecol Reprod Biol 2016;202:36-40.

34. Geisler ME, Ledwidge M, Bermingham M, McAuliffe $\mathrm{M}$, McMenamin MB, Waterstone JJ. Intrauterine insemination-No more Mr. N.I.C.E. guy? Eur J Obstet Gynecol Reprod Biol 2017;210:342-7.

35. Coppus SF, Land JA, Opmeer BC, Steures P, Eijkemans MJ, Hompes PG, et al. Chlamydia trachomatis IgG seropositivity is associated with lower natural conception rates in ovulatory subfertile women without visible tubal pathology. Hum Reprod 2011;26:3061-7.

36. Boujenah J, Montforte M, Hugues JN, Sifer C, Poncelet C. [Laparoscopy in ART?]. Gynecol Obstet Fertil 2015;43:604-11.

37. Verberg MF, Eijkemans MJ, Heijnen EM, Broekmans FJ, de Klerk C, Fauser BC, et al. Why do couples drop-out from IVF treatment? A prospective cohort study. Hum Reprod 2008;23:2050-5.

38. Custers IM, van Dessel TH, Flierman PA, Steures P, van Wely M, van der Veen F, et al. Couples dropping out of a reimbursed intrauterine insemination program: what is their prognostic profile and why do they drop out? Fertil Steril 2013;99:1294-8.

39. Lande Y, Seidman DS, Maman E, Baum M, Hourvitz A. Why do couples discontinueunlimited free IVF treatments? Gynecol Endocrinol 2015;31:233-6.

40. Troude P, Guibert J, Bouyer J, de La Rochebrochard E; DAIFI Group. Medical factors associated with early IVF discontinuation. Reprod Biomed Online 2014;28:321-9.

41. Dinelli L, Courbière B, Achard V, Jouve E, Deveze C, Gnisci A, et al. Prognosis factors of pregnancy after intrauterine insemination with the husband's sperm: conclusions of an analysis of 2,019 cycles. Fertil Steril 2014;101:994-1000.

42. Oddens BJ, den Tonkelaar I, Nieuwenhuyse H. Psychosocial experiences in womenfacing fertility problems--a comparative survey. Hum Reprod 1999;14:255-61.

43. Salvatore P, Gariboldi S, Offidani A, Coppola F, Amore M, Maggini C. Psychopathology, personality, and marital relationship in patients undergoing in vitro fertilization procedures. Fertil Steril 2001;75:1119-25.

44. Ohl J, Reder F, Fernandez A, Bettahar-Lebugle K, Rongières $\mathrm{C}$, Nisand I. [Impact of infertility and assisted reproductive techniques on sexuality]. Gynecol Obstet Fertil 2009;37:25-32.

45. Reder F, Fernandez A, Ohl J. [Does sexuality still have a place for couples treated with assisted reproductive techniques?]. J Gynecol Obstet Biol Reprod (Paris) 2009;38:377-88.

46. Shoji M, Hamatani T, Ishikawa S, Kuji N, Ohta H, Matsui $\mathrm{H}$, et al. Sexual satisfaction of infertile couples assessed using the Golombok-Rust Inventory of Sexual Satisfaction (GRISS). Sci Rep 2014;4:5203.

47. Piva I, Lo Monte G, Graziano A, Marci R. A literature review on the relationship between infertility and sexual dysfunction: does fun end with baby making? Eur J Contracept Reprod Health Care 2014;19:231-7.

48. Tao P, Coates R, Maycock B. The impact of infertility on sexuality: A literature review. Australas Med J 2011;4:620-7.

Conflicts of interest.-The authors certify that there is no conflict of interest with any financial organization regarding the material discussed in the manuscript. 